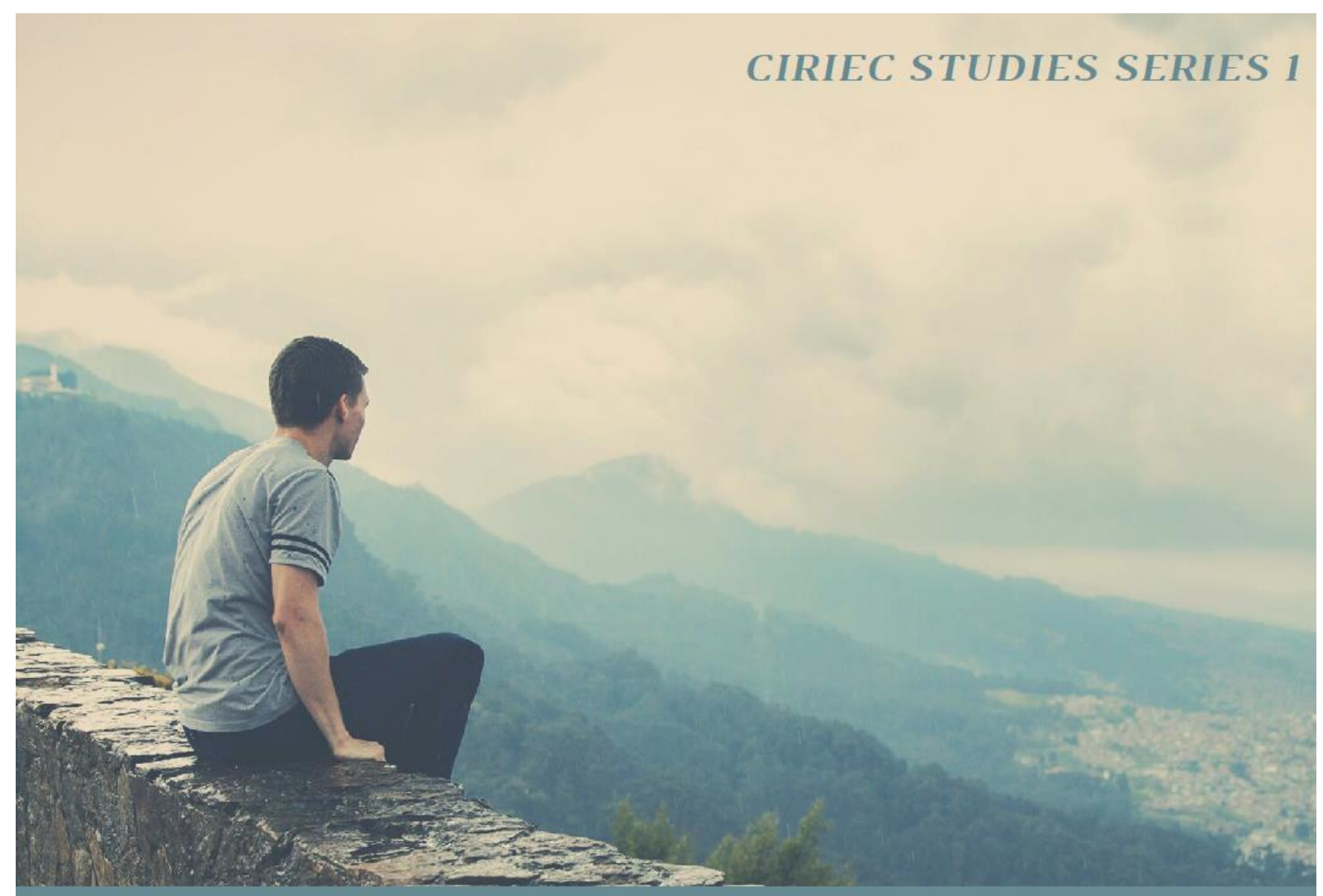

CHAPTER 8

THE DEVELOPMENT IN FRANCE OF PARTNERSHIPS BETWEEN DUBLIC AND SOCIAL ECONOMY ORGANIZATIONS AND THE NEW PARADIGM OF PUBLIC ACTION

Philippe Bance Jean-Philippe Milesy Christelle Zagbayou

Part of Providing public goods and commons. Towards coproduction and new forms of governance for a revival of public action by Philippe BANCE (dir.), 2018 
CIRIEC (International Centre of Research and Information on the Public, Social and Cooperative Economy) is a non-governmental international scientific organization.

Its objectives are to undertake and promote the collection of information, scientific research, and the publication of works on economic sectors and activities oriented towards the service of the general and collective interest: action by the State and the local and regional public authorities in economic fields (economic policy, regulation); public utilities; public and mixed enterprises at the national, regional and local levels; the so-called "social economy" (not-for-profit economy, cooperatives, mutuals, and non-profit organizations); etc.

In these fields CIRIEC seeks to offer information and opportunities for mutual enrichment to practitioners and academics and to promote international reflection and action

CIRIEC activities, publications and researches are realized with the support of
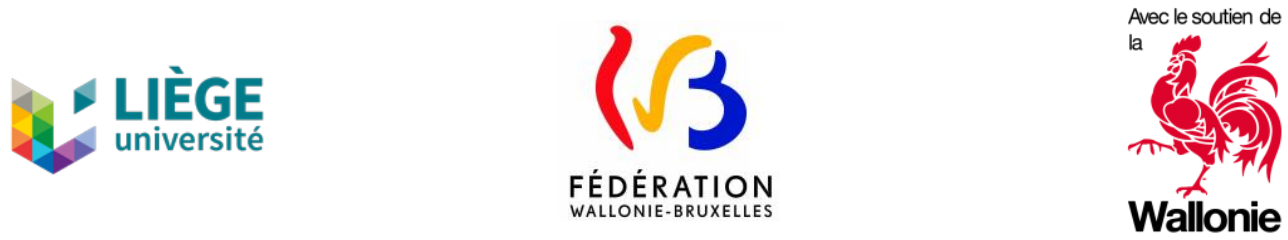

This publication has been peer-reviewed.

No part of this book may be reproduced in any form, by print, photocopy, microfilm or any other means, without prior written permission from the publisher. All rights reserved.

(C) CIRIEC aisbl, 2018

Université de Liège

Quartier Agora

Place des Orateurs, 1

Bât. B33, bte 6, BE-4000 Liège

ciriec@uliege.be; http://www.ciriec.uliege.be

BANCE, Philippe, MILESY, Jean-Philippe and ZAGBAYOU, Christelle. "The development in France of partnerships between public and social economy organizations and the new paradigm of public action / Chapter 8". In: CIRIEC and BANCE, Philippe (dir.). Providing public goods and commons. Towards coproduction and new forms of governance for a revival of public action. Liège: CIRIEC, 2018. (CIRIEC Studies Series; 1), pp. 163-183.

http://doi.org/10.25518/ciriec.css1chap8

This publication is indexed and available in $\underline{\operatorname{RePEc}}$ 


\title{
The development in France of partnerships between public and social economy organizations and the new paradigm of public action / Chapter 8
}

\author{
Philippe BANCE ${ }^{*}$, Jean-Philippe MILESY ${ }^{* *}$, Christelle ZAGBAYOU
}

\begin{abstract}
The chapter explains why and how the institutional and social transformations that have taken place in France during the last decades with the advent of the new public management are at the origin of new forms of cooperation between social economy organisations provided in the past by public organisations or private companies providing public services and in charge of the missions entrusted to them. Today, public and social economy partnerships are encouraged by public enterprises, public non-market organisations or public authorities, which see it as a means to extend public service delivery in a context of reducing financial resources. These transformations have the advantage of the cooperation of different organisations to maintain or increase public service provisions for the benefit of citizens. However, the future of this emerging model raises three main interrogations: the capacity of social economy organisations to retain their own identity by becoming largely providers of public organisations or authorities; the resilience of the fundamentally centralist conception which permeates the French model and limits the scope of these new partnerships; and last the banalization of social economy organisations as a result of the deployment of new public management and the neoliberal conception that limit the ability to co-construct the general interest with the different partners.
\end{abstract}

Keywords: cooperation; public action; social economy organisations; public organisations; public service provisions; multilevel governance

JEL-Codes: H41, L23, L31, L32, L33, L38

\footnotetext{
${ }_{* *}^{*}$ Normandie Univ, UNIVROUEN, CREAM, 76000 Rouen (France) (Philippe.Bance@univ-rouen.fr).

${ }^{* *}$ Rencontres sociales (France) (milesy@rencontres-sociales.org).
} 
Public-private partnerships (PPP) are often presented, in particular by European authorities, as a future solution for ensuring the development of public action programs. Public-social economy partnerships (PSEP) are less well known, being recent, especially in France. Nevertheless, they are expanding in line with the French process of decentralisation undertaken since the 1980's and they currently benefit from a real institutional recognition from national public authorities. The "Social and Solidarity Economy Act" of July 2014 thus aims to make the social economy (SE) an essential sector in order to respond to unfulfilled social needs and so that new entrepreneurs invest in this area. The purpose of this is thus to change the scale of a sector of the SE which already represents close to $10 \%$ of national production.

Today this recognition poses with new acuity the question of the development and the nature of PSEP. This contribution aims to study the transformation of the French model and the prospects it offers to PSEP. The first section is diachronic: it analyses the transformations of the institutional framework in which PSEP are deployed, in order to understand the current dynamic and its effects on the collaboration between public-SE. The second section is a synchronic analysis of PSEP in order to specify their nature. A third section concludes on the possibilities and limitations of the roll-out of this form of partnership in France.

\section{The institutional changes of the French model, sources of the roll-out of partnerships between public organisations and the SE}

To understand the reasons that led to the recent emergence and development of common measures in France between public organisations and the SE, it is useful to look back to comprehend the characteristics of the French model, and particularly the methods for implementing public action and social action, under the particular auspices of the public service. Starting with the origins of the post-war model, then from its transformations since the 1980's, we can indeed analyse the framework in which the transverse actions between public organisations and the SE occur.

\subsection{A post-war model of mono-construction of public policies to public regulation leant against "French-style public service", not conducive to cooperation}

Under the influence of Jacobinism, of the body of legal doctrine of the school of Léon Duguit and French economic engineers, public service in France after the second war became a major instrument of public and social action of public powers. The legal doctrine brought under the domain of the public service "all activity of which the accomplishment must be assured, resolved and controlled by the governments because the accomplishment of this activity is indispensible to the realization and development of social interdependence" (Duguit, 1923). The material approach of the public service justifies its existence by the service rendered to individuals and to society by completing duties in the general interest. The public authority positions itself at the centre of a system of representation: this approach returns to an ideology of the general interest, placed in the rousseauist tradition of general willingness and 
of Jacobinism (Rangeon, 1986). The general interest transcending the particular interest is embodied by the public authorities that interpret and realise it according to the circumstances by leaning on public service organisations.

This transcendent approach of the general interest is at the origin of a typical model of public action. The public sector is the main "instrument" of state action, responsible for social and territorial cohesion. It benefits from a cultural attachment at the root of a social compromise (Stoffaës, 1995). The social model also rests upon a system of social protection, bismarckien-like, fragmented according to professional structuring, but framed and regulated by public powers. Public action therefore anchors itself to an imaginary, benevolent state that remedies the insufficiencies or abuses of the market and has a shared idea in making public service the vehicle of national solidarities and social progress. The major attachment to this idea of public service finds its basis from the side of employees, of users, as well as of the high administrative state bodies. From the side of employees, the stability of employment, the statutory guarantees make public service a reinforcement of independence for personnel, of social advances and of the spread of social progress in the economy. From the users' point of view, despite the lack of means for certain activities ${ }^{1}$, public service allows the satisfying of social needs that are not sufficiently taken into account by the market and the social integration of those from disadvantaged categories. It gives the image of being interested in people rather than seeking profit ${ }^{2}$. Furthermore, the action of the high administrative state bodies plays an important role in the legitimisation of "French-style public service" with the population and political decision-makers, according to a unifying and centralist idea.

Based upon Vaillancourt's classification (2008) of the methods of construction of public policies, the French model can be considered as that of a "mono-construction": the authorities define the policies, without this meaning the exclusion of the private sector being involved in their implementation, in particular with the aim of making a profit ${ }^{3}$.

Indeed, during this period, France mobilised private companies among the operators of public service. The $19^{\text {th }}$ century left the legacy of a model referred to as delegated management, described in other words as public-private partnerships. The state or the local authorities concede the management of a public service to private operators by endowing the latter with the privileges of public power. The definition of public service duties and the allocation of concessions highlight the free choice of public authorities. The distribution of water is a typical example of French-style delegated management, the main part of the activity being principally conceded to three large private groups by the French local authorities.

\footnotetext{
${ }^{1}$ A typical example is the weakness of telephone investments up to the beginning of the 1970's.

${ }^{2}$ This makes the user not only a simple client but a citizen consumer.

${ }^{3}$ We can also refer to the presentation of this typology in the contribution to this work of Combes-Joret, Lethielleux and Reimat.
} 
But the predominant management style of the French public service leans largely on public ownership (local but mainly the state). The main role assigned to public ownership is the opposition raised to oligopolistic behaviour and annuitants of the large groups of delegated management, but also to the theoretical justifications brought by French economic engineers - particularly by Allais's theorem of maximum social return - to the integrated public monopoly.

If we can from now on refer to Vaillancourt and the mono-construction of public policies, the characteristics of the internal preparation methods in the public arena should be further specified. It concerns a plan in which interact, according to variable methods regarding the period concerned, the guardianship from one side and companies and organisations from the other side. Public organisations are indeed not there as simple implementation instruments of policies defined by a guardian. They are also carriers of their own strategies that reflect autonomy more or less widespread according to the company and the circumstances. This fact has meant that public enterprises could sometimes appear "uniformed" even "les bonnes à tout faire de la politique conjoncturelle » ['maid of all work' of cyclical/short-term policy] (Anastassopoulos, 1979). They are also presented as organisations that impose their views on authorities and highjack the regulator. EDF, often presented as a "state within a state" is the emblematic figure of this. The reality is multi-faceted. Public organisations on the one hand register their action in the framework of a model aiming to promote social and territorial cohesion. They make use of their own expert abilities and of their ability to implement innovations to justify their actions and assert their skills. Some managerial innovations such as marginal cost pricing, the social discount rate, the costs of failure, are some illustrations of this. In other terms, public organisations themselves internalise duties of general interest. But they can also be subjected to (all while searching to escape it) strong pressures from the supervising authority to actively engage them in duties of general interest. Public investments, even the large technology programs, such as nuclear, TGV and telephony, undertaken in the 1970's, are themselves written into in this problem of internalisation of missions in the general interest, which go beyond the framework of simple obligations of public service. This resulted in the existence of "life cycles of public enterprises within regulation" from the post-war period to the 1970's. They mark the involvement of public enterprises in the framework of proactive public policies, of which the effects are however (in particular in the case of overinstrumentalisation) strong disrupters to the financial health of companies, that which makes necessary the recovery of companies by an everyday acceptance of their behaviour after their roll-out (Bance, 2015).

Beyond this dialectic of public actors, France is, according to the typology of Enjolras (2008), very clearly a model of public governance. The public administrations and organisations are the principal contractors of public policies, and the governance 
is characterized as strongly technocratic ${ }^{4}$. Certain decisions taken also appear to be hardly democratic in many ways, due to a lack of consideration of the opinions and aspirations, both upstream and downstream, of civil society ${ }^{5}$. In this model, very little place is finally left for the action of SE organisations.

This type of construction and public governance found itself seriously called into question in the 1980's.

\subsection{The process of multi-level, neoliberal co-construction of public policies in France and its effects on the establishment of PSEP}

After the worldwide repercussions of the Washington consensus, the new directions taken with the process of European construction and of decentralisation, the French model experienced an institutional bifurcation. Based upon the typologies of Vaillancourt and Enjolras, we can consider that after the 1980's, it falls within a new paradigm of public action, that of neoliberal co-construction of public policies and of competitive governance but, one can say, multi-level in character. We can also ask ourselves if certain forms of resilience of the previous model and the emergence of new implementation terms for public action do not naturally stimulate forms of cooperation between the public economy and the SE, which are carriers of a coconstruction of public action.

The transformations experienced by the national model since the 1980's fundamentally stem from the emergence of governance that we can label as multilevel. This is mainly due to the loss of sovereignty of the national state and of the calling into question of the previous way of mono-constructed public governance. We can characterise the regime of multilevel governance by the advent of "nonhierarchical systems of negotiation, of regulation and of administration going beyond the traditional acceptance of the hierarchical and sovereign state as the ultimate decision-making and conflict-resolution arena" (Christiansen, 1996, p. 13). Here public stakeholders interact in the implementation of public policies but according to a scheme marked by a growing influence of competitive logic and according to a neoliberal method of co-construction. A double process explains its roll-out in France: on the one hand the new directions of the European construction; on the other hand decentralisation. This translates by calling into question the sovereignty of the state from both above and below and ultimately by a weakening of "capability" ${ }^{6}$ to lead public action (Bance, 2016).

\footnotetext{
${ }^{4}$ Here we can again refer this work to the presentation of the typology of Enjolras from Combes-Joret, Lethielleux and Reimat.

${ }^{5}$ EDF is in this respect particularly targeted in the choice of nuclear power that the company has largely valued under guardianship.

${ }^{6}$ Here we refer to the idea of "capability" put forward by Sen who understands by this an accounting for the ability and liberty of individuals to use their goods to choose their own lifestyle, to apply this to the states own collective ability in an international environment.
} 
After the Single Act of 1986, the states' public policy quickly eroded in Europe, in particular in their ability to undertake proactive public action and to mobilise public organisations to this end. The loss of sovereignty reduces their ability to implement industrial, monetary or macroeconomic policies. The phenomenon was fully expressed after the Maastricht Treaty (1993) that led to the establishment of the said policies of stability and growth in the European Union. As underlined by Fitoussi and Saraceno, new "social public norms" are thus in place, which banish the Keynesian or of-demand national policies, without a European alternative and despite a context of sluggish growth (Bance, 2012). These norms are characterised by a "pressure exercised on the European welfare states by the reduction in public spending and the commitment of structural reforms" (Fitoussi \& Saraceno, 2009).

The weakening of the capabilities of public action also comes from a loss of flexibility from public authorities regarding public market services within the national network. If the state or the local public authorities keep the ability to define public service duties, the European authorities, whether this concerns the Commission or the Court of Justice, possess since the 1990's, a power of control to judge the proportionality of state aid to the missions of public service companies in the network. This outbreak of a supranational judge and police fits with the logic of European integration, the companies being not only national but also contributing to transnational exchanges. The rupture is, however, radical towards the previous arrangements for governance of public action that allowed the state to fully mobilise their heritage for purposes of economic policy. We then see a phenomenon of normalisation of the behaviour of public enterprises under the effect of nitpicking European controls that are exercised by applying the so-called doctrine of "the private investor in the market economy". The central repository of company behaviours is that of an investor who looks for the return in "normal conditions" in a market economy, that is to say in a competitive market. This teleological idea is going to push for the systematic opening to competition, to eliminate all statutory barriers to entry and to an effective opening to competition in networked public services. This will be the case particularly in the sectors of telecommunications, the post, electricity and railways. The respect of the rules of the game of competition and sustainability of competitive market structures are the responsibility of independent administrative authorities in charge of sectorial regulation. In this way, the sectorial regulator sees themselves assigned far-reaching powers which are then removed from the state: powers of investigation, surveillance, regulation and sanction. The purpose is primarily to ensure that the historic operator does not abuse their dominant position, to protect incomers, to eliminate crosssubsidies and to resolve conflicts between competitors. However, this does not prevent public services being able to practice public service missions in these sectors: after having aroused strong controversy as to their legality ${ }^{7}$, the implementation of public service missions has been tolerated in European law provided they are formalised and clearly defined by the authorities. They can thus find themselves

\footnotetext{
${ }^{7}$ It took several years and several rulings (Corbeau in 1993, commune of Almelo in 1993, Altmark Trans in 2003) of the CJCE to declare the legality of it under restrictive conditions.
} 
compensated by the regulator... of which the financial margins are nevertheless very limited by the implementation of stability policy. This encourages public service missions with increasingly limited content.

A normalisation of the behaviour of public enterprises quickly arrived by an alignment with the management criteria of private companies: the objective of developing capital, the payment of dividends to the shareholder, flexibility in managing staff (including removing the status of civil servant). The new demands of public management in a competitive system erode the culture of social action of organisations. This is the situation at La Poste, for example, where today they look to monetise the assistance given to the most deprived users, local services, time available to listen, and where the number of post offices is being reduced across all territories... the non-market foundations of public service logic is also being called into question, otherwise carriers of social and territorial cohesion (Delfau, 1999).

If financial reasons limit the ability of public enterprises to accept extended public service missions (whether written into the law or not formalised in this way), these missions are nevertheless an important source of legitimacy for them. Public organisations are from then on incited to act in unison with other organisations to ensure or maintain sufficiently extended public missions allowing the enhancement of an action that rests fundamentally fixed, in its social representation, on serving the general interest. SE organisations, whose reason for being is not the search for profit but that of non-commercial common interest, which are inherently impregnated with the culture of serving the public and able to provide innovative practices, can from then on contribute to joint actions with public enterprises to more widely internalise general interest missions.

These reasons also apply to the roll-out of cooperation between SE organisations and of the non-commercial public sector. The latter are indeed subjected to, in the new institutional system of developing public policies, criteria based upon the doctrine of New Public Management. Spurred on by the establishment after 2001 of the Organic Act relating to finance laws (OAFL), the new doctrine intends that non-commercial public organisations take their own initiatives and develop innovations for better efficiency in the implementation of public duties (Fournier, 2015). The organisations are evaluated based upon performance indicators aimed to measure the degree to which results have been reached towards set objectives, while simultaneously seeking to limit the increase in public spending. This doctrine thus pushes the roll-out of joint actions with SE organisations: the partnerships can enrich and improve the efficiency of public organisations' action.

Public organisations' openness to SE partnership organisations must not, however, lead to neglecting the existence of an autonomous logic, which leads these organisations to consider that cooperation and partnerships need to be aligned with their own objectives. As these objectives, whether they concern the pressure of covering the costs and the distribution of dividends of public companies, or efficiency 
criteria assigned to non-profit public organisations, prove to be increasingly binding for public organisations, and this in a permanent way in the new institutional environment. These organisations are thus led to consider the partnerships as a means to meet formal objectives or where applicable as "additional soul" allowing the enhancement of their image through social actions or socially responsible actions.

To complete this analysis, it is appropriate to specify in what way the individual rationale of public powers is conducive to the development of public partnerships with the SE in the new system of multi-level co-construction of public policies. Indeed, here each level of government (supranational, national or infra-national) can find the way to introduce or re-introduce capabilities according to their idea of the general interest. This approach is placed within a complex game of coopetition between levels of government. Coopetition is characterized by the joint rationale of cooperation and of competition between the stakeholders involved (Brandenburger \& Nalebuff, 1996). In the European Union, the interactions of government levels derive from this willingness to both exercise their own options (frequently to the detriment of partners) and the necessity to sign up to a common public action (Bance, 2016). But faced with the loss of public capability and with the difficulties met to finance public action, each level of government can find useful energetic supplements in partnerships with the SE, which contribute to the general interest.

At supranational level, extroversion is a response to the critics concerning the strong weakening of the ability of direct public action resulting from methods of European construction since the Single Act. The European Commission has thus advocated the development of public private partnerships (PPP). Since 1999, "The Commission considers that the use of private investment to realize public infrastructures is a positive factor and one which is important to continue developing" (Com, 2000). Ten years earlier, the Commission drafted a notice (Com, 2009) "concerning the mobilization of private and public investment in view of a relaunch of the economy and a long-term structural transformation". In accordance with the market logic that drives European policies, it involves bringing the states to open up their markets to competition. One is also trying to remedy the crisis by innovative actions and "combining the abilities of public and private capital", in particular for large infrastructure projects, notably in the transport and energy sectors ${ }^{8}$. In this regard, the model of delegated management is also perceived as a response to the contemporary stakes in the globalisation of public services ${ }^{9}$. Public partnerships with the social economy can subscribe to a complementary logic of developing major and innovative projects. Thus the social economy is recognised by the Europe Strategy 2020 as a driver of inclusive growth, sustainable and as a provider of employment. Social innovations and social entrepreneurship have the support of

\footnotetext{
${ }^{8}$ The BEl created a centre of expertise to reduce the risks for private operators of PPP, a mechanism of technical assistance put in place for the scale of the project and Eurostat developed an accountancy doctrine for the partnerships.

${ }^{9}$ The international expansion of French companies in the water sector seen here as a reference model.
} 
the EU in the framework of the initiative "One Union of innovation" and of the initiative for social entrepreneurship.

At national level, partnerships with SE organisations and the revitalisation of the sector are seen as a source of economic development on which to build in the face of the weakening capability of the state regarding economic policy. Because, beyond the previous analysis concerning the reduced capacity of the state to proactively mobilise its organisations in the European multi-level system, since the 1980's the public market assets has known (and in fact, partially at least, of this weakness) privatisations on a very large scale. The weight of the public enterprise sector across the market economy as a whole excluding the agricultural and financial sectors of the French economy has thus fallen: in the added value of $19,3 \%$ in 1985 to a range of 5$5,7 \%$ during the period 2005-2013; in the fixed assets from 47,3\% in 1985 to 15,516,1\% from 2008 to 2013 (INSEE, 2016). Therefore, the state intends to focus, beyond PPP that can often prove to be costly and a source of long-term income for private operators (Mardy et alii, 2006), on the additional energy that can constitute the development of the SE. The SE is increasing since the beginning of the years 2000 and represents in 2016, according to the Ministry of the Economy and Finance, $10 \%$ of the GDP and $12,7 \%$ of private employment in France. It concerns, according to the minister Martine Pinville on the site (2016) of the Ministry of the Social Economy, after the adoption in 2014 of the law relating to the Social and Solidarity Economy, "allowing granting full growth to the social and solidarity economy... (to) stimulate an efficient and mobilizing dynamic, and to place this model to create employment and activities across all of our territories". In this perspective, putting into place synergy with public organisations is a tool for development.

Finally, at subnational level, the regional public powers have known, since the Defferre 1981-83 laws of decentralisation, a progressive extension of their competences for exercising and implementing their own public policies: initially in the areas of town planning, professional training and spatial planning; economic development (planning and programming amenities) in the 1990's; heritage protection, ports and airfield development, air quality and nature reserves preservation, since 2002; digital technology, European program management, the arrangement and sustainable development of the territories in the framework of the 2015 law relative to the new territorial organisation of the Republic (NOTRe) by the new regional plan for the arrangement and sustainable development of the territory (SRADDT). These new prerogatives, which also translate the roll-out of real territorial policies replacing territorialised policies (Autès, 2000) are here again carriers of partnerships and opportunities of co-construction of public policies with the SE sector: the territorial proximity, the ground knowledge of SE organisations facilitates collaborations with the regions. The proximity of SE organisations with subregional local and regional authorities (departments, metropolis, associations of municipalities, municipalities ...) also contributes to local partnerships. The pressures exerted upon the finances of local and regional authorities due to the transfer of competencies not entirely compensated for by the state does not limit any less the 
development of partnerships so great is the dependence of SE organisations towards public funding.

\section{Multiform cooperations and partnerships initiated with the SE by the public economy in the new institutional system}

If, as has been specified in the first section, institutional changes drive public actors to cooperate with SE organisations, the partnerships implemented take very specific, diverse forms that need to be better identified across practices on the ground. In this regard, one can identify the cooperations implemented under the impetus of various public actors: public companies, the state and finally local and regional authorities.

\subsection{Partnerships initiated by public enterprises}

Forms of cooperation between public enterprises and the SE are increasingly numerous in France. For reasons of civic and social responsibility, but also with an economic objective (to produce and sell goods and services), certain public enterprises choose to develop partnerships with Social and solidarity economy companies depending on the localities, the needs expressed and the material or financial resources available. Recently undertaken initiatives, under a partnership approach, by the largest French public groups namely La Poste, SNCF, EDF, regarding SE structures, will be presented here, by specifying in particular that, for each, this falls within an approach that is derived from a specific logic but based upon their own culture of social action (CIRIEC-France, 2016; Zagbayou, 2016).

- La Poste

The objective of the collaboration by La Poste group is to unite SE actors under various topics that have been identified as being common to both sectors. According to a working logic, that intends to be based upon mutual trust within a collaborative framework, La Poste wishes to develop innovative solutions and coproduce new value chains, in order to bring satisfactory answers to current social needs.

In their strategic plan "La Poste 2020: conquer the future ", ${ }^{10}$ various priority programs launched by the group are thus offered, in the framework of commitments made for implementation alongside actors of the SE of the Alliance Dynamique. The goal of this structure is to grow the SE by making the skills of voluntary employees of La Poste available to associations. This commitment officially taken on the $14^{\text {th }}$ of October 2014 in the presence of various actors of the SE such as ADIE, APAJH, COORACE, CRESUS, EMMAUS France, Fédération des parcs naturels régionaux de France, Secours populaire français ${ }^{11}$, is also an opportunity for La Poste to identify

\footnotetext{
${ }^{10}$ "La Poste 2020: conquer the future » is a project of conquest and development to serve the client, the work http://legroupe.laposte.fr/profil/la-strategie/a-la-conquete-de-l-avenir, (consulted on 2017/19/10).

${ }^{11}$ https://www.alliancedynamique.laposte.fr .
} 
new leverages of development. The first consultations between partners allowed defining five dynamic, supporting areas for the group:

Shared spaces: This area aspires to use the building stock of La Poste as leverage for local development. Resurrecting vacant buildings or sharing the premises occupied by La Poste with actors of the SE are examples of solutions aiming to revitalise territories and create new activities;

Banking products: La Banque Postale, which provides a quarter of La Poste group's revenue, plays a leading role in the Alliance Dynamique, which involves offering products tailored to the needs of actors of the SE. La Banque Postale thus displays its vocation to be bank and a citizen, extending its mission of universal, accessible public service to bank accounts through its 'livrets A' type bank books (Bance \& Rey, 2015);

Human resources: in the framework of l'Alliance, and in line with its commitments favouring the professional development of its collaborators, La Poste accompanies the professional projects of postal workers wishing to evolve towards the SE sector;

Purchasing: for several years, purchases are an integral part in CSR policy of the La Poste group. With this area, a willingness to reinforce the purchasing policy towards the actors of the SE is confirmed;

Energy transition: identified as one of the common priority projects in La Poste's strategic plan that makes energy transition a major program for the country. This area reaffirms the groups aim to contribute to the emergence of a new French energy model.

These five areas guide the thinking and the work of partners, who mobilise their networks and all of their skills to successfully meet the goals of I'Alliance Dynamique.

\section{- SNCF}

The SNCF's partnership approach with the SE sector falls within a tradition to which the public group underlines its attachment: the sense of public service and a high technical and commercial performance. With the purpose of translating these societal commitments and objectives, the societal division of the direction of sustainable development and the direction of purchases, along with various associations of the SE, undertakes various forms of cooperation in the given territories. The action of the SNCF thus falls within a partnership approach with the actors of the SE on one hand in the field of sustainable development, disability and employment and on the other hand, in solidarity purchases.

The societal centre at the heart of the direction of sustainable development

SNCF creates action plans in the framework of assistance in returning to work, to ensure that, through its own abilities as a large investor, buyer and service provider in 
the territories, it can increase the chances of excluded people to reintegrate themselves into society. In this perspective the group has judged it necessary to implement partnerships in a certain number of sectors of opportunity. There are also partnerships between the SNCF and the national network CHANTIER school, the FNARS, the ministry of justice, the national network of POLES EMPLOI - local missions for young people, with all the services that involve the regulation of the social/relationship with clients, precisely social mediation notably with FRANCEMEDIATION $^{12}$. It is leverage which allows the creation of jobs, job integration workshops, "green" workshops, the treatment of abandoned railways (named vegetal), the recycling of waste, the exploitation of materials, short cycles, etc.

In addition to these actions, the SNCF works with several associations specialised (PROMEVIL and many others) in subjects such as extreme poverty, loitering in stations, prostitution, and multiple substance abuses. This collaboration aims to improve the services of social regulation and social prevention in trains, thus allowing the reduction of incidents (setting-off alarms, stopping trains...) and serious or annoying incidents.

\section{Solidarity purchasing}

Since 2008, the SNCF purchasing directorate has included in its social responsibility strategy, the aim of directing its purchasing towards the SE. The SNCF group aspires in particular to make 33.3 million euros worth of solidarity purchases in 2015 to 50 million euros in $2017^{13}$.

Solidarity purchases contribute to financing services of protected and adapted sectors ${ }^{14}$, of the sector for inclusion through economic activity (direct or through social inclusion articles in calls for tender) and from fair trade. The establishment of inclusion workshops occurs with specialist associations that allow people outside of employment to work and be trained. The quality of services provided by protected and adapted sectors and of inclusion through economic activity is comparable to those of classic companies, with a global cost supported by public funding (local authorities). These solidarity purchases contribute to the maintenance and development of employment for people with disabilities in accordance with regulation, like that of people outside of employment, in its capacity as a socially responsible company. In 2015, around 13,5 million euros worth of purchases were counted among protected and adapted sectors for 550 employees against

\footnotetext{
${ }^{12}$ http://www.sncf.com/fr/groupe, (consulted on 2017/19/10).

${ }_{13}$ Direction générale des achats responsables, Groupe SNCF, Livret du Bilan des Achats Responsables Groupe SNCF, 2015, http://www.sncf.com/fr/fournisseurs/achats-responsables, (consulted on 2017/19/10).

${ }^{14}$ The objective of these sectors is to offer a professional activity to people with a handicap by ensuring they have a medical, social and educational support. This monitoring aims to give an opportunity for a potential exit from the protected sector (ESAT) towards an adapted company or the ordinary sector.
} 
19 million euros worth of purchases counted among the sector for inclusion for 230 employees $^{15}$.

\section{- EDF}

EDF displays, by its partnerships with SE organisations, its implication in the preservation of biodiversity. In particular, the group works with environmental associations in the framework of its "policy of sustainable development" by assessing the environmental risks linked to the use of resources and natural spaces. Thus the group supports the actions for the Ligue pour la Protections des Oiseaux (LPO). The partnership between these two sectors is also evident from conferences, festivals or common programs organised with the view to sensitise people, physically and morally, to the importance of biodiversity and the avifauna. EDF also provides the LPO with access to a group of experts who carry out field studies in order to develop skills and propose solutions for protecting spaces and species. The EDF group's directorate of Sustainable Development conducts in-depth analysis with services specializing in naturalist studies in four sites of the Ligue pour la Protections des Oiseaux. Furthermore, the EDF Foundation, with its partners which are le Ministère de la Ville, de la Jeunesse et des sports, Pro Bono Lab and Recherches et Solidarités, le Réseau national des maisons des associations, HelloAsso, and Associations Mode d'emploi, organise prize days for the best associations working in categories such as environmental education, the fight against discrimination, health and prevention high risk behaviour, access to culture for young people, the fight against precariousness. The partnerships between the SE sector and the EDF are also working on questions of precarity and energy transition. The group looks to correct, across these different actions, a fundamentally centralist, self-managed image and to remove the criticisms relating to the roll-out of energy production that is principally nuclear in its origin.

\subsection{Partnerships driven under the aegis of the central state}

Here the support brought by the state to the SE is illustrated from two perspectives: the institutional recognition and legitimisation by the state of the action from SE organisations; the aid brought by the Caisse des dépôts et consignations.

The recognition by the state of the role of SE organisations to lead actions in the general interest: the example of social housing

The state has gradually turned towards practices of delegation to associations of actions of general interest. It is particularly the case for the management of public service housing. Here the associations play an essential role in the identification of social needs (reception and dealing with the homeless). The Besson Law of $31^{\text {st }}$ May 1990 regarding the right to housing has thus made the non-profit sector an important operator in the framework of the policy of access to housing for deprived

\footnotetext{
${ }^{15}$ Direction générale des achats responsables, Groupe SNCF, Livret du Bilan des Achats Responsables Groupe SNCF, 2015, http://www.sncf.com/fr/fournisseurs/achats-responsables, (consulted on 2017/19/10).
} 
people. This law gave associations the right to manage actions and services with a social vocation. As such, these associations are able to benefit from the financial aid of the state ${ }^{16}$ : PLATS (Prêt locatif aidé très social), ANAH (Agence nationale de l'habitat). The Fédération nationale des associations d'accueil et de réinsertion sociale (FNARS) and l'Union nationale interfédérale des œuvres et organismes privés sanitaires et sociaux (UNIOPSS) are large voluntary networks that thus play a major role in the fight against the exclusion of disadvantaged people. By the recognition and support of the state, these large national associations of solidarity became institutionalised.

The financial support of the state by the intervention

of the group Caisse des Dépôts et Consignations

The group Caisse de Dépôts et Consignations (CDC) plays an important role in supporting public policies and notably in fulfilling the objective of developing the SE in application of the 2014 law $^{17}$. Under the authority of parliament, CDC is a shareholder of large French companies in charge of the transformation of regulated savings into long-term investments, of the management of private funds protected by the law (funds originating from the ministry of justice, from social security, from institutional clients) and of "pension and solidarity funds" originating from retirement systems of the civil service. In 2015, accompanied by six private partners, CDC launched in this perspective an investment fund of 50 million euros to improve the system of financing the SE and to solve the major problem of lack of funding to which operators of the SE are confronted. The aim of these investment funds is therefore to cover the financial needs of social and solidarity companies, all being eligible: associations, cooperatives, mutuals, foundations and commercial businesses with a predominately sector-specific cover on the social, the medical-social or even energy transition. The associations and young organisations in an accelerated period of growth and bringing innovation are priorities here along with older organisations (in existence for at least 6 years) wishing to transform themselves, change their image or scale, for investments comprised of between 1 million and 5 million euros. As for suppliers of large-scale projects, they are accompanied by fund managers and by a committee of experts (for investments comprised between $€ 100000$ and $€ 500000$ per project).

\subsection{Partnerships under the aegis of local authorities}

The interest and dynamic of local and regional authorities

By loans, grants or by the intervention of calls for projects, local authorities indeed bring financial support to the operators of the SE who follow the actions of territorial interests. They also accompany the latter by the provision of material goods or staff in order to promote and highlight their various activities.

\footnotetext{
${ }^{16}$ http://www.vie-publique.fr/politiques-publiques/hebergement-urgence/etat/, (consulted on 2017/19/10).

${ }^{17}$ Regarding the support of the state, we can add the Banque Publique d'Investissement (Bpifrance), reserved more than 500 million euros which are reserved for this sector.
} 
The major interest shown recently in the SE by local public decision makers is highlighted by the call (launched in June 2015 by 300 elected persons representing more than 130 regional authorities) supporting the sector. Communities strongly reaffirm their interest in the SE, as well as their willingness to put in place regional policies in support of this sector. In this framework, it involves financing works of research and innovation (for example studies on social impact), the development of platforms promoting access to mobility, town and country planning and transport (allowing integration of social provisions in markets linked to the railway infrastructure).

Regional authorities also include the SE in the production of their sustainable development plans in addition to creating and financing collective experimental approaches (approaches in industrial ecology). There are several partnerships in the area of employment, professional training and learning, education, culture, sport, agriculture and food.

The example of partnerships in non-commercial public services through the reform of the organisation of the school rhythm in primary schools

The partnership dynamic of local authorities with the SE is illustrated, in the noncommercial public sector, with the reform of the organisation of the school rhythm in primary schools launched by the state in $2013^{18}$. The objectives displayed by the state are "to better distribute school hours during the week, to lighten the school day and to program the sequence of teaching to moments where pupils have optimum powers of concentration"19. This new organisation raises the question of the care of pupils outside of school time. The regional authorities, and in particular the municipalities who are responsible for the material resources made available for primary school children, must from now on confront the expression of a social demand connected to school time and an extension of extra-curricular time of publicservice education (centred upon new sporting, cultural and artistic activities). This also involves the collective care of children up until the end of the afternoon including Wednesdays and to ensure the reform is compatible with the availability of many parents.

Educational projects of regional development (PEDT) give the town a leading role in order to better consider local needs based upon an analysis of the characteristics of state school and to widen the offer of suitable extra-curricular activities. Several municipalities have since turned towards local organisations to better perform and to lower the cost of the new demands of the reform. Multi-year agreements have been adopted with the establishment of local consultation committees that enable the explanation of the social demand and to structure the different school and extra-

\footnotetext{
${ }^{18}$ Décret $n^{\circ} 2013-77$ du 24 janvier 2013, (consulted on 2017/19/10).

${ }_{19}$ http://www.education.gouv.fr/cid66696/la-reforme-des-rythmes-a-l-ecole, (consulted on 2017/19/10).primaire.html\#L\%E2\%80\%99essentiel sur\%20la\%20r\%C3\%A9forme\%20des\%20rythmes\%20\%C3\%A0\%20l\%E2\% 80\%99\%C3\%A9cole\%20primaire, (consulted on 2017/19/10).
} 
curricular activities ${ }^{20}$. Priority education, cultural and sports organisations have been called upon to reform, along with other partners, the development of extra-curricular activities $^{21}$ based upon a shared idea.

An initial evaluation undertaken in 2016 by the French Mayors' Association united in the framework of the association of the principal national towns " France urbaine $\|^{22}$ remarks on, beyond the particular financial difficulties encountered in the implementation of the reform, the willingness of public authorities to develop partnerships between the various stakeholders and to revitalise the actions of associations.

\section{Conclusions: establishing complementarity in the public economy - SE, a source of synergies but also interrogations on the ability to co-construct public action}

The establishment of complementarity of public economy organisations and the SE seems to follow, even more so than usual public-private partnerships, an approach based upon a strong philosophical and doctrinal anchor: the original principles of limited profit-making or the absence of a main motive of capital, the primacy of the person over capital, social criteria and the common or general interest are indisputable sources of unification and synergising of the two sectors. Public economy and social economy organisations have thus for their basis to respond to the needs of populations, at local and national level. This places them as key actors in the implementation of an "economy of needs", which proceeds from Fournier's analysis (2013) of the satisfaction of all means to ensure human development (such as education, health), everyday life (social protection, housing...) democratic life (justice, police, social links...), economic development (credit, research, innovation).

The complementarity and the proximity of values can therefore lay the foundations in France (belated, it is true, due to the centralism of the initial idea) of a new model which, as demonstrated by the works of Ostrom, can lean on "the capacity of local users to solve problems of the commons" (2010, p. 14). The human is at the heart of all approaches on which decision makers, entrepreneurs, activists, citizens jointly work on. This ensures the strength of a partnership built more upon differentiated logic by actors of the SE and the public economy. These partnerships reunite human resources and in capital allow the roll out new forms of public action in the territories.

\footnotetext{
${ }^{20}$ For example, we will refer to the devices put into place by the commune of Créon in Gironde http://www.caissedesdepotsdesterritoires.fr/cs/ContentServer?pagename=Mairieconseils/MCExperience/Experience\&cid=1250265991975, (consulted on 2017/19/10).

${ }^{21}$ Various examples are given in this respect in the report of the committee following the reform of school hours in 2015 http://www.education.gouv.fr/cid95088/rapport-du-comite-national-de-suivi-de-la-reforme-desrythmes-educatifs-une-dynamique-favorable-engagee-sur-l-ensemble-du-territoire.html, (consulted on 2017/19/10).

${ }^{22}$ http://www.courrierdesmaires.fr/59521/reforme-des-rythmes-scolaires-lheure-de-levaluation-pour-troisassociations-delus/, (consulted on 2017/19/10).
} 
They are concerned with leading institutions to handle in-house innovative issues in response to shared social objectives.

There are the foundations of a future development in France of partnerships between the organisations of the SE and local authorities or public organisations, of a willingness of stakeholders to collaborate, to commit on both sides to work to meet common objectives of keeping social cohesion and of satisfying the general interest. If in France the realisation of the potential and contribution of the SE to the economy was somewhat tardy, today this is now firmly fixed in an institutional, multi-level framework that leaves more space for territorial development policies.

The partnerships are, in this perspective, potentially bearers of a new model of coconstruction of public policies, of an alternative to the traditional very top-down French idea. These opportunities would be all the more real if the partnership logic would instate "new public values" that were more attentive to processes than to results, especially at the local level, leading to break with the dominant conception of the new public management.

The limitations to the development of cooperation between the public economy - SE and the emergence of a new model nonetheless remain important. They have in our view a triple dimension: the transformations required of the SE to fall within the new dynamic; the resilience of the French centralist model; the institutional framework of constructing public policies within which falls the action of stakeholders.

\subsection{Transformations of SE organisations}

The voluntary world, which for a long time dominated the SE, functioned under largely informal types of management. Today SE companies have experienced profound evolution, arising from a strong need for professionalisation and renewal of skills. The partnerships with local authorities or public organisations often remain, however, difficult to establish due to the slowness of decision making from SE actors, the heaviness of procedures at work, the loss of time at the design stage, the implementation of a project, or still the lack of visibility of SE organisations on numeric platforms (Zagbayou, 2016). The conditions for developing partnerships and their sustainability assume therefore, as considered by many actors and analysts, a strong increase in the level of professionalism of SE organisations and their expert abilities in building partnerships.

However, the integration of more professional types of management by the SE raises the question of the very identity of the organisations in this sector. A strong concern of many SE actors indeed rests on the risk of the banalisation of their organisations: to see organisations restricted to adopting behaviour increasingly closer to that of actors in the market, taking their inspiration directly from private sector management methods. The phenomenon also designated in the literature of institutional isomorphism brings with it a fundamental calling into question in SE organisations' ability to preserve the very values that make them (Enjolras, 1996). The phenomenon 
has largely touched the French mutualist sector just as public company sectors and non-market public organisations. The associations are themselves touched by the opening up to competition, as with the example of the domestic aid sector under the effect of "mandatory" rules in the context of restrictions in public finances (Petrella, 2012). They are likely to take a large part of their range out of partnerships that are meant to be based upon ideas and values claiming to be intrinsically different from that of the market economy.

\subsection{The resilience of the French-style centralist idea}

Although the process of decentralisation has been underway for several decades and French-style public service dominated by large public enterprises has somewhat diminished, the hegemonic idea of public action conceived and driven from above, under the aegis of policy makers and public organisations has not disappeared. Decentralisation very often gives rise to the transfer of the centralist political approach of the national level towards inferior territorial levels. This centralist culture brings the decision makers and the large public organisations to consider SE organisations as real partners, but to want to instrumentalise them. Witnesses of several representatives of the $\mathrm{SE}^{23}$ thus condemn the tendency of local and regional authorities to want to unilaterally define the rules of the partnerships between the SE and the public sphere. They do this by showing much reluctance in fully involving SE organisations in the decision making process, even though they recognise them as efficient technical operators. With this in mind, the powers or public organisations make associations and SE organisations play the role of simple operators of public policies or to assert the strategies of public organisations (CIRIEC-France, 2016) and reject the logic of the co-construction of public policies.

The phenomenon of coercive instrumentalisation threatens the SE even more so as their organisations are very dependent on public funding and their professionalisation and expert capacity in the implementation of joint projects is weak. The shrinking financial resources of local and regional authorities in the context of the crisis in public finance and the transfer of competencies not matched by the state inevitably pressure them. To fix this, the relationship between the SE and the pubic economy should henceforth be modified by the establishment of a new culture of public action that radically breaks with current forms of paternalism to build upon the capacities for initiative and innovation unique to the organisations of the SE.

\subsection{The coercive element of neoliberal co-construction of public policies}

As specified further above, since the 1990's, partnerships between the public economy and the SE follow a new paradigm of neoliberal and multi-level coconstruction of public action. This new paradigm is restrictive for the partnerships initiated by the organisations. Indeed it is based upon a teleological construction of a

\footnotetext{
${ }^{23}$ P. Frémeaux, The social and solidarity economy looks to find its way, Alternatives Economiques, $\mathrm{n}^{\circ} 288$ February 2010, 2010.
} 
competitive market and new norms of action for decision makers and the public organisations that have been largely presented in the first section of this study. A commercial approach in the general interest and a restrictive normalisation of public attitudes ensue. In this context, the SE organisations strongly risk being systematically affected in their value system, as has already happened to public organisations. The normalisation of organisations' behaviour as that of an 'investor trained in the market economy" particularly pushes the development of public-private partnerships rather than public-SE; the position of the European Commission is revealing in this respect, despite the high cost that could arise with the formula in the long term and the questions that it provokes in France in terms of economic and social efficiency (Mardy et alii, 2006).

The types of partnerships to follow will henceforth depend on the perpetuation or the renewal of the standards of public action and of the scale of the missions in the general interest or of the public service that the authorities will heed and be able to promote in the territories. If a strong willingness from public decision makers concerning social action, in particular at national level, can change the paradigm of public action, its transformation could also result in local dynamics and innovative cooperations if it holds the belief at societal level.

\section{References}

ANASTASSOPOULOS, J. P., "Les bonnes à tout faire de la politique conjoncturelle ", in Revue française de gestion, 1979, $\mathrm{n}^{\circ} 20$.

BANCE, P., Public Action in the Crisis, Commission scientifique 'Economie publique' du CIRIEC-France, PURH, 2012.

BANCE, P., "Entreprise publique et politique économique : une combinatoire d'avenir ? " in BANCE, P., L'internalisation des missions d'intérêt général par les organisations publiques, Commission scientifique 'Economie publique' du CIRIEC-France, PURH, 2015.

BANCE, P., REY, N., "La Poste, emblème du service public à la française ou futur groupe leader européen ", in CIRIEC, BERNIER, L., Public Enterprises Today: Missions, Performance and Governance, Peter Lang, 2015.

BANCE, $P$., « L'Etat stratège : Etat réduit ou à capacité étendue en régime de gouvernance multi-niveaux ", in BANCE, P., Quel modèle d'Etat stratège en France ?, Commission scientifique 'Economie publique' du CIRIEC-France, PURH, 2016.

BRANDENBURgER, A. M., NALEBUfF, B. J., Co-opetition, Currency/Doubleday, 1996.

CHRISTIANSEN, T., Reconstructing European Space: From Territorial Politics to Multilevel Governvance, in EU Working Papers, Robert Schuman Centre 96/53, European University Institute, 1996. 
CIRIEC-France, Transversalité entre Economie publique et Economie sociale et solidaire au service de l'intérêt général, Etude en exécution de la convention conclue avec le ministère de l'Economie, de l'Industrie et du numérique, décembre 2016.

Commission des communautés européennes, Communication interprétative de la Commission sur les concessions en droit communautaire, 2000/C 121/02.

Commission des communautés européennes, Communication de la Commission au Parlement européen, au Conseil, au Comité économique et social européen et au Comité des régions du 19 novembre 2009 concernant la mobilisation des investissements privés et publics en vue d'une relance de l'économie et d'une transformation structurelle à long terme: développement des partenariats public-privé, 2009, $\operatorname{COM(2009)\quad 615}$ final (consulted on 2017/19/10).

DELFAU, G., La Poste : un service public en danger, L'Harmattan, 1999.

DUGUIT, L., Traité de droit constitutionnel, Editions de Boccard, 1923.

ENJOLRAS, B., " Associations et isomorphisme institutionnel », in RECMA, 1996, n² 261.

CIRIEC, ENJOLRAS, B., Gouvernance et intérêt général dans les services sociaux et de santé, Peter Lang, 2008.

FIROUSSI, J. P., SARACENO, F., Normes sociales et politiques européennes, Revue de l'OFCE, 20091 $\mathrm{N}^{\circ}$ 102, http://www.ofce.sciences-po.fr/pdf/revue/14-102.pdf, (consulted on 2017/19/10).

FOURNIER, J., L'économie des besoins. Une nouvelle approche du service public, Odile Jacob, 2013.

FOURNIER, J., Architecture et déclinaison des missions publiques, in BANCE, P., L'internalisation des missions d'intérêt général par les organisations publiques, Commission scientifique 'Economie publique' du CIRIEC-France, PURH, 2015.

INSEE, "Les entreprises publiques ", in Les tableaux de l'économie française, édition 2016, https://www.insee.fr/fr/statistiques/1906721?sommaire $=1906743$ (consulted on 2017/19/10).

MARDY, F., TROSA, S., VOISIN, A., Les partenariats public-privé, Collection Repère, La Découverte, 2006.

OSTROM, E., "A long Polycentric Journey", Annual Review of Political Science, Vol. 13, 2010, http://www.annualreviews.org/doi/full/10.1146/annurev.polisci.090808.123259, (consulted on 2017/19/10).

PETRELLA, F., Aide à domicile et services à la personne : les associations dans la tourmente, Presses universitaires de Rennes, 2012.

RANGEON, F., L'idéologie de l'intérêt général, Economica, 1986.

STOFFAËS, C., Rapport de la commission du Commissariat général au plan, Services publics, question d'avenir, Editions O. Jacob, La documentation française, 1995. 
VAILLANCOURT, Y., "Social Economy in the co-construction of public policy, La démocratisation des politiques publiques: Une vision canadienne et québécoise", Canadian Social Economy Research Partnerships, Occasional Paper Series, 3, 2008, http://socialeconomyhub.ca/sites/socialeconomyhub.ca/files/CSEHubOP3YvesVaillancour t.pdf, (consulted on 2017/19/10).

ZAGBAYOU, C., Les partenariats entre entreprises et services publics et entreprises de I'Economie sociale et solidaire : une approche territoriale, Mémoire de master Economie et développement des territoires, Université de Rouen, 2016. 


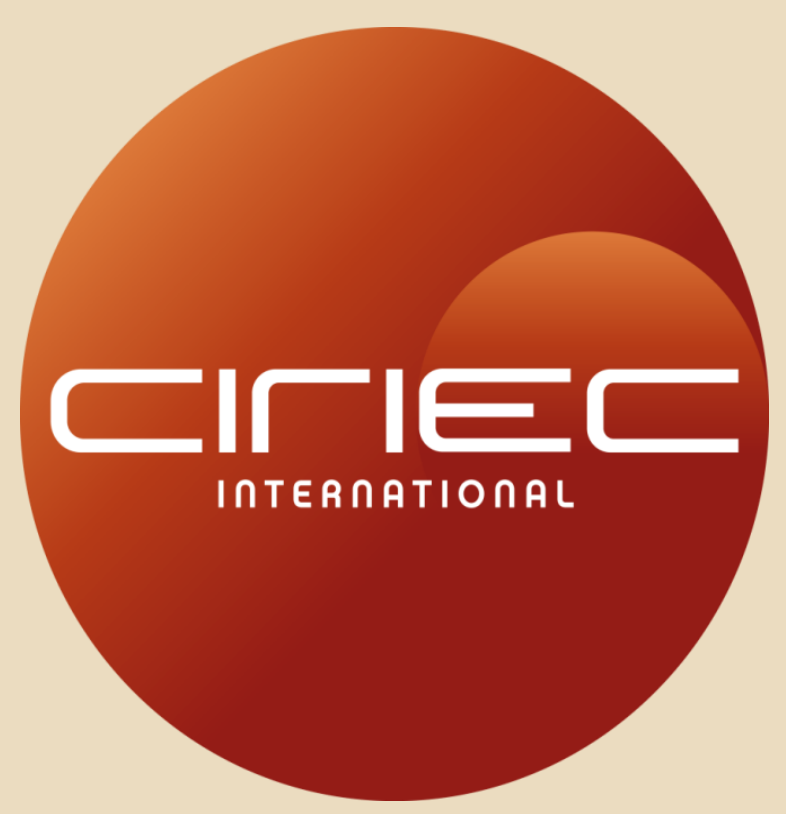

The CIRIEC STUDIES SERIES proposes research results from working groups and commissions of the CIRIEC scientific network in both social and cooperative economy and public economy.

To facilitate accessibility to those research works, this electronic series is proposed in open access, on CIRIEC's website, but also as new series in RePEC.

Each study is available and downloadable as a whole document but also chapter by chapter.

x ciriec@uliege.be

\#ww.ciriec.uliege.be

(https://ideas.repec.org/s/crc/chapte.html 